\title{
Escenografías del deseo urbano. El escaparate como espacio fantasmal y límbico en el cine de vanguardia de los años 20
}

\author{
Ma Soliña BARREIRO \\ Departamento de Medios Audiovisuales \\ Escuela Universitaria Politécnica Tecnocampus Mataró \\ Universitat Politècnica de Catalunya \\ mbarreiro@tecnocampus.cat
}

Recibido: $12 / 02 / 2014$

Modificado: $27 / 10 / 2014$

Aceptado: 28/11/2014

\section{Resumen}

El escaparate y la luz eléctrica son dos de los elementos clave de la escenografía cinematográfica de la modernidad. Se desafía a la escasez y a la oscuridad, se inflama un deseo inconsumable a todas horas del día y de la noche. El cine de los años 20, y en especial el de vanguardia, se llenó de vidrios, luces y mercancías, que pueden ser analizados como una metáfora crítica del cine en sí mismo. La pantalla, como membrana interactiva, proyecta un deseo, un estilo de vida que en apariencia es alcanzable, pues la imagen no miente, es transparente, pero que en ocasiones no resulta más que una ficción que fetichiza las condiciones sociales de existencia. A través del análisis de las imágenes del cine de los años 20 y en especial del cine de vanguardia, y de los textos y proyectos de la época, se presenta un ensayo que incide en la función estética e ideológica de esta escenografía efímera urbana que es el escaparate, entendiendo que vitrina y cine son dos caras del mismo simulacro de vida en la sociedad moderna.

Palabras clave: escaparate, luz eléctrica, cine de vanguardia, fetichismo, Berlín, sinfonía de una gran ciudad.

Title: Scenographies of Urban Desire. The display window as the border between reality and the ghostly space of desire in the 20's Avant-garde cinema

\begin{abstract}
Display-windows and electric lights are capital in the set design of 20's cinema. They defy material needs and night darkness; they foster an inconsumable desire night and day. The cinema of the 20s, especially Avant-garde cinema, filled up their images with glass, lights and merchandise, this feature can be analyzed as a critical metaphor of cinema itself. The screen as interactive membrane projects a kind of desire and lifestyle that are apparently achievable: mechanical image does not lie; it is transparent as the display-windows. But often fiction cinema fetishizes the social conditions of existence. This paper studies the display-window and cinema as an ephemeral urban set through 20's film, texts and projects from an aesthetic and ideological point of view.
\end{abstract}


BARREIRO, Ma Soliña (2014): "Escenografías del deseo urbano. El escaparate como espacio fantasmal y límbico en el cine de vanguardia de los años 20" [en línea]. En: Ángulo Recto. Revista de estudios sobre la ciudad como espacio plural, vol. 6, núm. 2, pp. 65-83. En: http://www.ucm.es/info/angulo/volumen/Volumen06-2/articulos04.htm. ISSN: 1989-4015 http://dx.doi.org/10.5209/rev_ANRE.2014.v6.n2.47584

Keywords: display window, electric lights, Avant-garde cinema, fetishism, Berlin: Die Sinfonie der Grosstadt.

\title{
Índice
}

1. Deseo inquietante y dominio en Berlín

2. La falsa transparencia y el deseo inconsumable

3. Cine-escaparate o deconstrucción de la fábula

4. El tiempo de las arquitecturas efímeras

El escaparate es el artefacto de deseo omnipresente en la ciudad de los años 20. La mercancía y el deseo plenamente unificados encerraban a los viandantes en carriles de cristal y luz, rebosantes de deseos listos para consumarse por medio de la adquisición. El compañero de paseos por Berlín de Walter Benjamin, Franz Hessel, describía fascinado como

\begin{abstract}
A lo largo de la calle Seydel se ven fantasmas en los escaparates, las muñecas de las fábricas de bustos y cabezas de cera [...] portando camisas, vestidos, abrigos y sombreros. iQué interesante es ver las cabezas de cera de los maniquíes! Con sus bocas puntiagudas te provocan, de sus pequeños ojos sale una mirada que parece gotear como si de veneno se tratara [...]. Es excitante su grado de desnudez. Rebosan desnudez dorada y despiden reflejos plateados y no tienen nada más que zapatos marrones [...]. Pero en Büstenhof también hay piernas aisladas. También hay extraños dispositivos [...]. Todo tiene su explicación pero yo me quedo absorto y perplejo ante esa cantidad de seres, de miembros de seres, dispositivos y rostros, algunos de los cuales llevan gafas. (Hessel 1997: 48-49)
\end{abstract}

Lo inquietante de los objetos sexualizados y provocadores, la mezcla de tecnología mecánica y eléctrica en los escaparates y la presentación de todas las facetas de la vida como algo consumible iban configurando una escenografía efímera del deseo, omnipresente y constantemente renovada por medio de los escaparates. El cine de vanguardia reconstruye la experiencia de ese deseo fantasmagórico, de ese "simulacro de vida" y reenvía una imagen crítica y a la vez autorreflexiva: si la vida en la calle está mediada por el escaparate, también lo está por el cine. Escaparate y cine separan al individuo de sus condiciones de vida por medio de la generación de un mundo de ensueño de consumo y éxito en el caso de los escaparates, de conducta y éxito en el del cine.

Un travelling nocturno y eléctrico de escaparates provocadores e inquietantes. Puede ser en Las noches eléctricas (Deslaw, dir., 1930), Berlín, sinfonía de una gran ciudad (Ruttmann, dir., 1927) o incluso en Adelante Soviet (Vertov, dir., 1926). El escaparate y la luz eléctrica son dos de los elementos clave de la escenografía 
cinematográfica de la modernidad. Se desafía a la escasez y a la oscuridad, se inflama un deseo inconsumable a todas horas del día y de la noche. Este artefacto omnipresente fascinaba por sus posibilidades tanto en el Este como en el Oeste; cuando el crítico vanguardista soviético Sergei Tretiakov visita Berlín, siente el embotamiento de los sentidos para atender a otra cosa que no sea el escaparate luminoso, y piensa en su posible uso revolucionario. Autores de vanguardia como Léger, Duchamp o Dalí decoraron escaparates; Sergei Eisenstein desarrolló un proyecto nunca filmado, Glass House, en donde el fetichismo y la falsa transparencia de la sociedad capitalista se revelarían al público en una película que transcurriría dentro de un edificio de paredes, techos y suelos totalmente transparentes. El cine de los años 20, y en especial el de vanguardia, se llenó de vidrios, luces y mercancías, que pueden ser analizados como una metáfora crítica de sí mismo. La pantalla, como membrana interactiva, proyecta un deseo, un estilo de vida que en apariencia es alcanzable, pues la imagen no miente, es transparente; pero que en ocasiones no resulta más que una ficción que fetichiza las condiciones sociales de existencia.

A través del análisis de las imágenes del cine de los años 20 y, en especial, del de vanguardia, y de los textos y proyectos de la época, se presenta un ensayo que incide en la función estética e ideológica de esta escenografía efímera urbana que es el escaparate, entendiendo que vitrina y cine son dos caras del mismo simulacro de vida en la sociedad moderna.

\section{Deseo inquietante y dominio en Berlín}

La Europa de entreguerras estaba sumida en un ensueño de deseo que se presentaba como alcanzable a través del consumo de mercancías. Las mercancías se sexualizaban y los cuerpos se mercantilizaban. Fetichismo y fantasmagoría oscurecían la comprensión de las relaciones de producción. La mediación de todos aquellos procesos vitales que, sin embargo, se presentaban como inmediatos y directos, creaban simulacros de experiencia, "simulacros de vida"1 ${ }^{1}$, vacíos de su verdadero contenido.

Los escaparates son elaborados como experiencia espacial, tanto en su organización interna como en su localización en uno de los núcleos experienciales de la ciudad: la calle. Sin embargo, es fundamental el elemento temporal constitutivo de la idea de

\footnotetext{
${ }^{1}$ Rilke, en una carta dirigida a Von Hulewitz en 1929, se mostraba preocupado por las modificaciones en la naturaleza de las cosas, por su transformación en "cosas vacías e indiferentes, apariencias de cosas, simulacros de vida..." pues "las cosas animadas, vividas, consabidas de nosotros declinan y no pueden ya ser sustituidas. Somos tal vez los últimos que hayan conocido todavía tales cosas" (Rilke apud Agamben 2006: 77-78).
} 
escaparate. El cambio y la recomposición cíclica de las mercancías expuestas marcaba los ritmos del consumo; siempre lo mismo pero presentado eternamente como nuevo, y marcando las épocas en las que la novedad debía ser consumida. De ahí su naturaleza de espacio arquitectónico efímero.

Los escaparates contribuían a la creación o potenciación de los deseos, que se presentaban ya materializados tras sus vidrios. Al encarnarse en una mercancía, el deseo se trasladaba de la esfera interna a la externa, y se presentaba como accesible y fácilmente consumable por medio de su adquisición. Se producía un simulacro de deseo en la exposición y un simulacro de consumación en la compra. Sin embargo, la gran proliferación de mercancías convertía el deseo en inconsumable, porque era imposible poseer todos los objetos en los que se había materializado una parte de ese deseo, siendo tan sólo posible un proceso de consumo inacabable e incompleto. Se presenta, pues, una instrumentalización del deseo para fomentar el consumo y la insatisfacción: la proliferación de nuevas mercancías nunca colmará el deseo porque éstas son infinitas, no abarcables mediante el consumo, que se nos presenta como la vía de consumación de ese deseo. El escaparate es el dispositivo que permite este proceso, en el que tanto la mirada como el propio deseo quedan comercializados. En Berlín, sinfonía de una gran ciudad (Ruttmann, dir., 1927), asistimos al comienzo de una relación entre dos personas que se ven a través de un escaparate, y vemos también cómo los maniquíes de los escaparates marcan los ritmos vitales, anticipando las actividades diarias de los habitantes de la ciudad.

Berlín presenta la crítica más lacerante a la deshumanización del deseo cuando median los escaparates. En ella podemos identificar la crítica a la mediación experiencial (deseo y relaciones humanas) y la idea freudiana de lo inquietante.

La estructura y el tratamiento de la película se organizan de manera que los espectadores tienen la impresión de que son los maniquíes de los escaparates quienes rigen las vidas de los ajetreados humanos. Cada cambio de momento del día, de actividad o de ritmos viene precedido por la imagen de un autómata o de un maniquí que adelanta esa actividad, impeliendo a los humanos a seguirlo. El montaje genera en el espectador la sensación de animación de los maniquíes, que parecen observar irónicamente, desde su pedestal inmóvil, su dominio sobre los humanos. La animación de lo inorgánico no sólo aparece como posible, sino como institución dominante de la vida humana. Los maniquíes en pijama la observan, y la ciudad duerme; las persianas de algunos escaparates se levantan, y la ciudad se activa; un autómata cocinero mueve su cucharón animando a comer, y la ciudad detiene su actividad para ir a comer. Y así con todas las actividades. Siegfried Kracauer también 
se había percatado de cómo en esta película "los seres humanos más bien se ven forzados a incorporarse a la esfera de lo inanimado" (Kracauer 2002: 176).

En esta interpelación maniquí-humano tienen especial importancia las relaciones sexuales y amorosas. Describiremos dos secuencias. En la primera de ellas, un hombre y una mujer elegantes conversan discretamente en la calle, se intercala la imagen de un maniquí femenino cuyo vestido levanta el viento y la de un autómata masculino que hace girar con el pie una rueda que insufla energía a una bombilla que se enciende; tras esta metáfora de deseo sexual inflamado, el plano siguiente muestra cómo ambos personajes se van juntos. Ese mismo autómata de la rueda y la bombilla aparece en la escena de Berlín descrita en la literatura sobre la película como una escena de prostitución: una mujer vestida de negro deambula entre los escaparates mirando a la gente; entonces, elige a un hombre, lo sigue y se miran a través de un escaparate que hace esquina. La mercantilización de su cuerpo observado a través del escaparate surte efecto, y el hombre camina rápidamente hacia ella, se encuentran y se marchan juntos. Aparece entonces de nuevo el autómata que hace que una bombilla se ilumine moviendo una rueda.

Estas imágenes pueden leerse como una simbiosis del fetichismo marxista y el fetichismo freudiano, como veremos más adelante. Asimismo, la mecanización del sexo transforma los tiempos y las pulsiones orgánicas en tiempos artificiales y previsibles.

El contraste en el tratamiento entre las tomas de maniquíes y las de personas es significativo de la intención crítica del filme. Los maniquíes y los autómatas están individualizados (sus rostros, sus actitudes), mientras que los humanos que realizan esas acciones son indiferenciables, sus rostros no pueden distinguirse bien, como consecuencia de la distancia y de la multitud. Esto contribuye a que aumente la sensación de desasosiego respecto de la animación de lo inorgánico y a que se genere la sensación de sometimiento y de falta de autonomía de las masas humanas. Situar una producción material destinada a exhibir ropa (los maniquíes) en situaciones humanas (amor, socialización, comida) es ya una forma de extrañamiento. De esta forma, se genera la duda sobre la animación de lo inorgánico. Freud y Jensch destacaron como caso por excelencia de lo siniestro la "duda de que un ser aparentemente inanimado, sea en efecto viviente; y a la inversa, de que un objeto sin vida esté en alguna forma animado" (Freud en Bueno y Peirano 2009: 228). Freud cita en su artículo otro elemento que resulta ser esencial en el cine de vanguardia a la hora de generar extrañamiento siniestro: la repetición.

Esta idea de repetición y extrañamiento se observa en Ballet mécanique (Léger y Murphy, dirs., 1924), y no por azar aparece en la secuencia de un escaparate de medias. Los maniquíes que las lucen 
son piernas de mujer cercenadas, una pierna que se sitúa como derecha y otra como izquierda. El montaje consiste en un cambio de planos a ritmo mecánico de reloj: en cada plano se colocan las piernas en distintas posturas, en el movimiento de esas dos piernas inertes, cada tic es una postura, un fotograma, sin movimientos intermedios. Se sitúan lateralmente hacia la derecha, hacia la izquierda y luego de frente se abren, entonces aparece un reloj entre ellas, ocupando el lugar del órgano sexual femenino. La sexualización de los maniquíes de medias, cercenados y exhibidos en una vitrina, genera una sensación inquietante basada en dos aspectos: por una parte, se observa la ironía sobre el sexo como un ejercicio cronométrico en el que, para ser exitoso, han de cumplirse una serie de fases y movimientos mecánicos y, por otra, aparece la idea de un cuerpo femenino descompuesto, conformado por partes reemplazables, que puede generar placer sin que sea siquiera necesario que esté íntegro, sólo hacen falta las piernas y el reloj como órgano sexual.

Rien que les heures (Cavalcanti, dir., 1926) también puede servir de ejemplo: un hombre mira lascivamente fuera de campo, coge unas medias y comienza a ponerlas delicadamente en una pierna. Al abrirse el plano descubrimos que su objeto de deseo es un maniquí femenino.

\section{La falsa transparencia y el deseo inconsumable}

La proyección de valores subjetivos en los objetos consumidos contribuía a que la definición de la identidad de los individuos se produjera a través de la ostentación de su consumo. La identidad se podía adquirir en las tiendas. Se producía una mitologización del deseo y de la compra; los deseos se materializaban en un objeto desligado de su naturaleza de uso, y la posible compra de ese objeto iba más allá de la necesidad física, se centraba en lo inmaterial inconsumable. La identidad, sin embargo, nunca termina de construirse objetualmente, lo mismo que tampoco acaba nunca de satisfacerse el deseo, porque los objetos son infinitamente diversos y llenos de matices en el modo en que el capitalismo los produce.

Las mercancías son "símbolo de algo y a la vez de su negación que puede mantenerse sólo al precio de una laceración esencial" (Agamben 2006: 70). Este aspecto del fetichismo lo analizó Freud en el coleccionismo de objetos metonímicos, en su virtualidad y en su incolmabilidad. Agamben, en su análisis del artículo de Freud "Fetichismus", asegura: 
En cuanto presencia, el objeto-fetiche es en efecto algo concreto y hasta tangible; pero en cuanto presencia de una ausencia, es al mismo tiempo inmaterial e intangible, porque remite continuamente más allá de sí mismo, hacia algo que no puede nunca poseerse realmente [...]. Esta ambigüedad esencial [...] explica [...] que el fetichista tiende [sic] infaliblemente a coleccionar y multiplicar sus fetiches. (Agamben 2006: 72)

Los escaparates mediaban entre la esfera interna de la conciencia y el objeto externo, y entre la esfera de la producción y la del consumo, separando al productor de aquello que producía por medio de la mistificación del producto. Los escaparates contribuían a la alienación de los trabajadores en relación al producto de su propio trabajo, esto es, al fetichismo de la mercancía. Marx lo describió en El Capital (1867) como un proceso en el que las propiedades de las mercancías quedan adscritas como inherentes y objetivas a las mercancías y no como adquiridas gracias al trabajo humano y, de esta forma, el valor de uso (social) se escinde del valor de cambio.

A primera vista, una mercancía parece un objeto trivial, obvio. De su análisis resulta que es una cosa muy complicada, llena de sutilezas metafísicas y de caprichos teológicos. En cuanto valor de uso no hay nada misterioso en ella, ya la considere bajo el punto de vista de que con sus propiedades satisface necesidades humanas, o que recibe estas propiedades como producto del trabajo humano [...]. Pero en el momento en que se presenta como mercancía, se transforma en un objeto sensiblemente suprasensible [...]. Lo misterioso de la forma de mercancía es que les refleja a los hombres los caracteres sociales de su propio trabajo como caracteres objetivos de los productos pero no es más que la relación social determinada de los mismos hombres, la cual adopta aquí la forma fantasmagórica de una relación entre cosas. (Marx 2000: 101-103)

La absorción del valor de uso por el de cambio supone que las relaciones sociales de producción se trasladen a relaciones objetuales. Las mercancías, así, "parecen dotadas de vida propia", como hemos visto en el caso de Berlín y como se puede también constatar en la escena final de Coeur Fidèle (Epstein, dir., 1923), donde los autómatas de la feria parecen tomar el dominio del destino de la pareja.

Las condiciones de producción estaban escondidas tras la fascinación transparente y luminosa de los escaparates urbanos. Ni el trabajo ni la explotación traspasan la opacidad de ese cristal ideológico. El cristal y su transparencia se habían convertido en símbolo del triunfo de la razón humana. En la Exposición Universal de 1851, un palacio de cristal que había influido en toda la arquitectura posterior, formal e ideológicamente. 
Las exposiciones universales pueden considerarse como un símbolo de esta dialéctica entre la supuesta razón y el fetichismo de la mercancía. Presentadas como muestra del progreso humano, combinaban técnica y ensueño, por eso el Cristal Palace, erigido en el Hyde Park de Londres, era un marco perfecto para acoger la fascinante novedad de los ingenios industriales de la Exposición. Todo el recinto sin tabiques internos estaba al alcance de la vista. La luz, la altura, lo agradable de la temperatura y esa visión de conjunto de todo el progreso industrial que se exponía en su interior, creaba un ensueño hermoso de convivencia entre técnica y naturaleza. Este edificio superó todo jardín, estación o invernadero que anteriormente se hubiera realizado en cristal y hierro. Y una vez finalizada la Exposición, no fue desmantelado, transformando en permanente el carácter de fascinación transitoria de estas construcciones. Las exposiciones universales eran los escaparates del progreso, que periódicamente querían renovar la fe de la gente en el avance de la sociedad capitalista. Al nivel de la calle, cada día los escaparates cumplían una función similar pero imbricada en la cotidianeidad. EI escaparate es una puesta en escena de seducción tanto durante el día como durante la noche, gracias a la iluminación eléctrica. Los organizadores de las exposiciones universales pronto se dieron cuenta de la transformación que los escaparates introducían en la fisonomía urbana moderna y los incluyeron en la Exposición Universal de Milán en 1906. Fue significativamente un escaparate de La Samaritaine el que se presentó en Milán; La Samaritaine abría una nueva etapa en la venta y exposición de mercancías, el gran centro comercial parisino, entonces en construcción, venía a confirmar el fin de los pasajes, estudiados años después por Walter Benjamin.

Los escaparates proliferaron en la ciudad y aparecieron los primeros centros comerciales, plagados también de ellos. Su extensión transformó radicalmente la topografía urbana y la percepción de la arquitectura en la ciudad; los ojos del caminante no superaban la altura del escaparate que se deslizaba tras él, al avanzar como único elemento reconocible de los edificios. Algunos comentaristas de la época hablaron de sinfonía de escaparates por su representación organizada, geométrica y rítmica de las mercancías. En el cine podemos ver como algunos travellings desde vehículos generan también esta sensación sinfónica.

Los escaparates se erigieron en "membrana espacial interactiva", conectando a los viandantes con la arquitectura moderna y sus interiores. La relación exterior-interior de los escaparates era un reclamo que proponía una falsa transparencia y accesibilidad visual al interior, donde se hallaba el deseo encarnado en mercancía y que parecía al alcance de la mano. Luz y vidrio contribuían a la sensación de accesibilidad e inmaterialidad y hacían que pasara inadvertida su imposición visual e ideológica. El cristal es "a la vez la 
proximidad y la distancia, la intimidad y el rechazo de ésta, la comunicación y la incomunicación [...] se puede ver pero no tocar, el escaparate es a la vez mágico y frustrante, epítome de la estrategia publicitaria" (Baudrillard apud Lungstrum 2001: 147-148).

La idea del escaparate se empleó también para vender un estilo de vida. Las cristaleras de los cafés y de los salones de baile ofrecían una imagen idílica de la ciudad y del tiempo libre. Aparecían en la calle como pantallas, exhibiendo el ambiente de diversión, luz y música del interior. Pero no siempre estaban al alcance de la participación; los escaparates del ocio, como los de mercancías, también elaboraban un deseo sólo alcanzable por partes, y si el dinero era suficiente para poder entrar. En La petite marchande de allumettes (Renoir, dir., 1928), un restaurante cálido está justo del otro lado del cristal, pero la cerillera exhausta y aterida de frío no puede entrar. Los protagonistas de Amanecer (Murnau, dir., 1927) sí pueden, sin embargo, dedicar un día a penetrar en los escaparates del ocio urbano, tan sorprendentes para ellos por su origen rural; la fantasmagoría radica aquí en que esa introducción en el ocio reconcilia a la pareja. Los escaparates tenían la función mediadora (y mixtificadora) entre la esfera de la producción y la del consumo y la cultura.

La novedad de la comercialización de la mirada urbana se consolida en los años 20, pero aparece a finales del siglo XIX. Se documentan grandes escaparates de vidrio alrededor de 1880 en los Estados Unidos de América, y hacia 1900 aparecen en Europa (Almacenes Tietz, Berlín). En los años 20, las artes comenzaron a integrarse en esta actividad. Aparecieron los escaparates modernistas en París y Praga; en Berlín, los influidos por la Wiener Werkstätte. En los años 30 llegaron los escaparates surrealistas como los de Dalí y Duchamp. Diferentes ferias y exposiciones se encargaban del particular, como la de las Arts Décoratifs et Industrielles de París en 1925 , en la que Léger se enroló como escaparatista. El vidrio como elemento decorativo y arquitectónico se extendía y se presentaba como epítome de los valores luminosos, transparentes y racionales de la época; arquitectos como Le Corbusier, Walter Gropius o Mies van der Rohe habían hecho del vidrio materia prima de sus construcciones.

Esa supuesta racionalidad y transparencia, además de ocultar y mixtificar las relaciones de producción, tenía otra parte negativa, la vigilancia y el anonimato. Las construcciones en cristal generan una dialéctica de la vigilancia. Parece que cuanto más cristal hay, menos privacidad existe y mayor es la vigilancia y el control.

La profusión arquitectónica en cristal, y toda la dialéctica que tras ella se halla, provoca que cuando Eisenstein llega a Alemania en 1926 le sobrevenga la idea de la película nunca llevada a cabo Glass House. Al descubrir en Berlín el uso de cristal en la arquitectura, 
imagina una "serie de situaciones paradójicas de naturaleza satírica destinada a demostrar la lógica del mundo capitalista" (Eisenstein y Albera 2009: 7). Este proyecto se desarrolla cuando Eisenstein llega a Estados Unidos de Norteamérica; allí descubre en el New York Times Magazine una fotografía de una maqueta de la Glass Tower de Frank Lloyd Wright que se adapta a lo que tenía en mente. Lleva sin éxito su proyecto a varias productoras americanas. Eisenstein nunca filmará esta película pero tampoco la abandonará; "el proyecto de película deviene [...] en un medio de reflexionar sobre la naturaleza de lo fílmico" (Eisenstein y Albera 2009: 12).

Lo más significativo de Glass House es la crítica a la sociedad de la falsa transparencia. Eisenstein proponía esta crítica, por una parte, a través del extrañamiento perceptivo, es decir, en este filme se dificultaría la capacidad de discernir lo que se ve para poner en duda la supuesta transparencia y accesibilidad del vidrio: "Al principio, el cristal como motivación para puntos de vista inhabituales. El extrañamiento del punto de vista. Después como profundización de la expresión psicológica" (Eisenstein y Albera 2009: 36). Por otra parte, incidiría en la crítica de la espectacularización de la vida a través de la exhibición pornográfica de todos sus aspectos: desde la calle los viandantes podrán ver a los habitantes de la casa participando en espectáculos de cabaret, teniendo discusiones 0 suicidándose.

El impacto de la luz eléctrica fue fundamental en la nueva percepción de la ciudad moderna: la electricidad hacía la noche habitable, abolía lo desconocido y materializaba la idea de la transparencia iniciada por el vidrio. Los observadores de la Exposición Universal de 1889 tenían claro que "el hierro y el vidrio serán los agentes que caracterizarán el siglo XX y le darán su nombre". El impacto eléctrico fue en aumento $y$, al inicio del nuevo siglo, con motivo de la Exposición Universal de París de 1900, Paul Morand no pudo sino ironizar sobre la obsesión eléctrica:

Resuena entonces una risa extraña, crepitante, condensada: la del Hada Electricidad. Del mismo modo que lo hace la morfina en los tocadores de 1900, ella triunfa en la Exposición [...]. El público se ríe de las palabras: "Peligro de muerte", escritas sobre los postes eléctricos. Saben que la Electricidad cura todo, incluso las neurosis a la moda. Es el progreso, la poesía de los humildes y de los ricos [...]. La Electricidad se acumula, se condensa, se la transforma, se mete en botellas, se la extiende en cables, se la enrolla en bobinas, después se la descarga sobre las fuentes, se la emancipa sobre los techos, se la desencadena en los árboles; es la plaga, es la religión del 1900. (Morand en AA VV 1983: 113)

Pronto se fue extendiendo el uso de la electricidad en los escaparates, aunque hasta 1922 no se generaliza. Entre 1926 y 1927 
BARREIRO, Ma Soliña (2014): "Escenografías del deseo urbano. El escaparate como espacio fantasmal y límbico en el cine de vanguardia de los años 20" [en línea]. En: Ángulo Recto. Revista de estudios sobre la ciudad como espacio plural, vol. 6, núm. 2, pp. 65-83. En: http://www.ucm.es/info/angulo/volumen/Volumen06-2/articulos04.htm. ISSN: 1989-4015 http://dx.doi.org/10.5209/rev_ANRE.2014.v6.n2.47584

la Oficina de Escaparates Luminosos de Alemania logró iluminar un $70 \%$ de los escaparates en 46 ciudades alemanas. El uso de la electricidad en las calles de Berlín era tal que cuando Sergei Tretiakov visita la ciudad habla de "Lichtalkoholiker" y, aún así, considera que estos mecanismos podrían aportar enseñanzas útiles en la renovación perceptiva de las ciudades soviéticas.
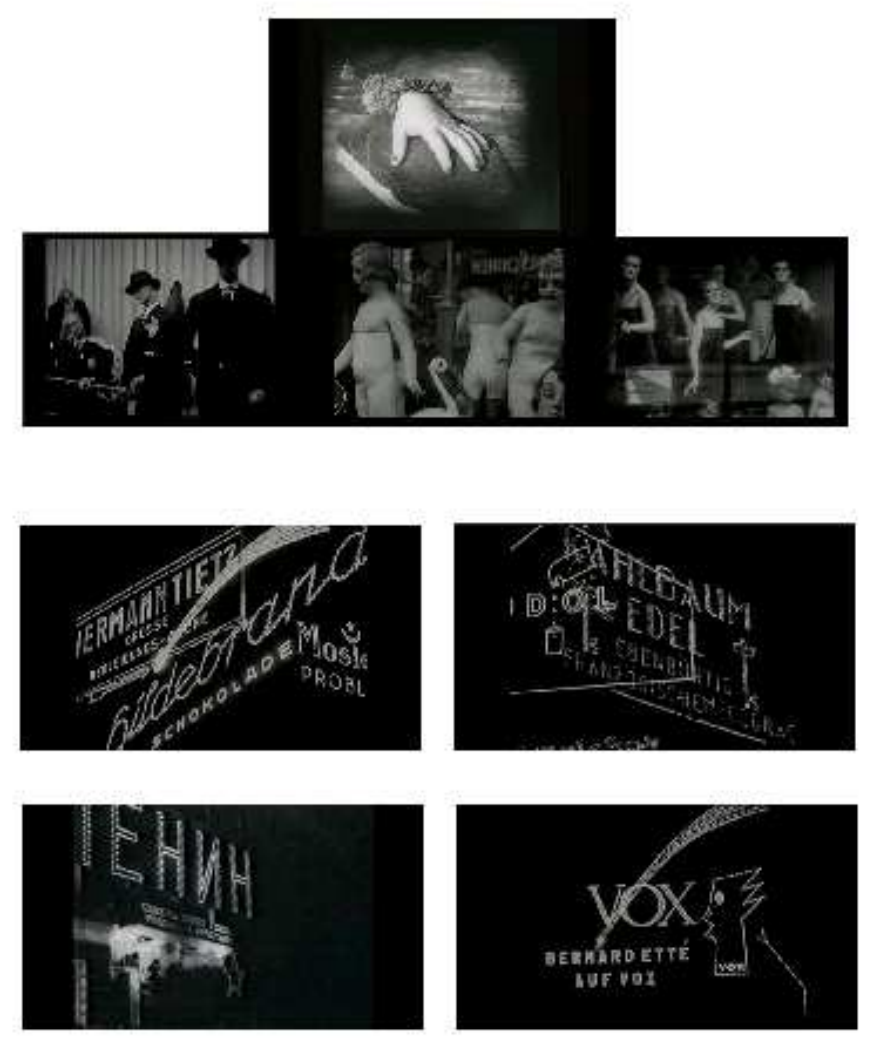

Figura 1. Fetichismo, simulacros de deseo y objetos inquietantes en $E I$ hombre de la cámara (Vertov, dir., 1929) y Berlín (Ruttmann, dir., 1927).

Reclamos luminosos en Berlín y La sexta parte del mundo (Vertov, dir., 1926).

Las películas de la época reflejaron el impacto eléctrico en la ciudad y en la percepción. Tempranamente el cine tiene acceso al registro de las noches modernas. En 1905, el pionero del cine Edwin S. Porter desarrolla una película más sensible que le permitirá filmar los letreros luminosos de Coney Island at night (Porter, dir., 1905) en Estados Unidos. Esta experiencia hará que el cine se llene de letreros luminosos y que los cineastas de vanguardia los recojan también en sus películas como reflexión material sobre lo que es el cine: tan sólo la estimulación que ejerce la luz sobre los haluros de plata. Así se pueden explicar algunas secuencias con letreros luminosos en EmakBakia (Ray, dir., 1926) o en Ballet méchanique (Léger, dir., 1924). Les nuits eléctriques (Deslaw, dir., 1930) es la única película de 
vanguardia que trabaja las luces nocturnas como único tema, "un tema de vanguardia", según Deslaw, quien explicaba por qué lo había escogido con las siguientes palabras: "El reclamo de los reclamos, la proyección luminosa de las luces, la iluminación general, itorrencial! de una ciudad, he aquí lo que me ha tentado de este tema" (Deslaw 1929: 120).

Janet Ward Lungstrum reflexiona sobre el reflejo del que desea en el propio escaparate, sobre cómo éste se integra en lo deseado tras el vidrio y cómo entra en juego la ciudad que lo rodea al reflejarse en el escaparate. Trabaja sobre la película $M$, el vampiro de Düsseldorf (Lang, dir., 1931) con la hipótesis de que ésta expone una relación entre el escaparate y los crímenes sexuales. El que desea se refleja en el escaparate, la niña deseada también, lo mismo que sus objetos de deseo; el dispositivo del escaparate termina potenciando el deseo del agresor. Y concluye que

Esta película sugiere astutamente que la cultura de las superficies en Weimar ha producido, a través de la bancarrota de los últimos años de la República, no sólo imágenes de ensueño para las masas en sus Schaufenster [escaparates, en alemán en el original], sino también una pulsión agresiva de consumo a toda costa: un asesino que es a la vez víctima de las estructuras de consumo de la fantasías y un asaltante de los consumidores que no sospechan (aquí personificados en la virginal inocencia de una niña pequeña). En los últimos estertores de Weimar, ir de escaparates se había convertido en algo peligroso. (Lungstrum 1999: 159)

Lo que tomamos de esta idea de Ward Lungstrum es la proyección de lo deseado y de quien desea en la misma pantallaescaparate $y$, a su vez, la frustración provocada por una transparencia que permite desear y ver pero que incomunica al espectador con su objeto de deseo. El proceso de generación y frustración del deseo de los escaparates se convierte en metáfora y epítome de un sistema que promete el éxito individual a través del uso de la razón instrumental pero que lo bloquea al no funcionar en los términos prometidos.

\section{Cine-escaparate o deconstrucción de la fábula}

El cine contribuye también a ese proceso de proyección de un deseo que parece alcanzable por lo accesible y transparente del medio fílmico pero que asimismo resulta frustrado. La pantalla cinematográfica puede ser entendida como escaparate y las mercancías como el contenido del cine ficción. Organizando la realidad en ficciones de frenesí, amor y éxito social, mostraba la vida de modo fetichizado al público, le sugería que la felicidad estaba a la vuelta de la esquina, tras la pantalla y, que si no la atrapaba, era sólo por su torpeza. 
El cine es un escaparate de mercancías culturales que, por su naturaleza, son a su vez creadoras y/o amplificadoras de la fantasmagoría que generan. El cine como pantalla-escaparate es el punto de unión entre la esfera productiva y la cultural (en breve, entre la infraestructura y la superestructura), por lo que su posición como nexo y garante de la reproducción del sistema de consumo los lleva a reproducir y a reflejar las características de una esfera en la otra. El cine tiene un estatus de interior-exterior, de dentro y fuera de la conciencia, de exposición pública y a la vez individualizada. Ocupa un espacio límbico en la conciencia similar al que habita la mercancía. La mercancía puebla los escaparates, limítrofes entre lo interno y lo externo; éstos parecen mostrar todo a través de la transparencia del cristal y crean, sin embargo, una mitologización del deseo. Éste se materializa en un objeto desligado de su naturaleza de uso, y su compra va más allá de la necesidad física, se centra en lo inmaterial inconsumable. Con el cine ocurre algo similar, la reproductibilidad mecánica de lo real parece mostrar todo sin ocultaciones, como el cristal del escaparate, y, sin embargo, fetichiza los valores subjetivos al encarnarlos tanto en objetos como en objetos-personajes.

Los cineastas de vanguardia percibieron esta dialéctica del medio fílmico y, de ahí, su desafección, en general, por el cine narrativo. Algunos de ellos se dedicaron al cine de lo real y otros fueron más allá desarrollando un metacine que pusiera al descubierto el funcionamiento del dispositivo para desvelar la fantasmagoría que atenazaba las conciencias. Entre estas películas que desvelan el proceso de producción de la imagen desde la propia pantalla-fetiche destacan El hombre de la cámara (Vertov, dir., 1929) y Emak-Bakia (Ray, dir., 1926). 

la ciudad como espacio plural, vol. 6, núm. 2, pp. 65-83. En: http://www.ucm.es/info/angulo/volumen/Volumen06-2/articulos04.htm. ISSN: 1989-4015

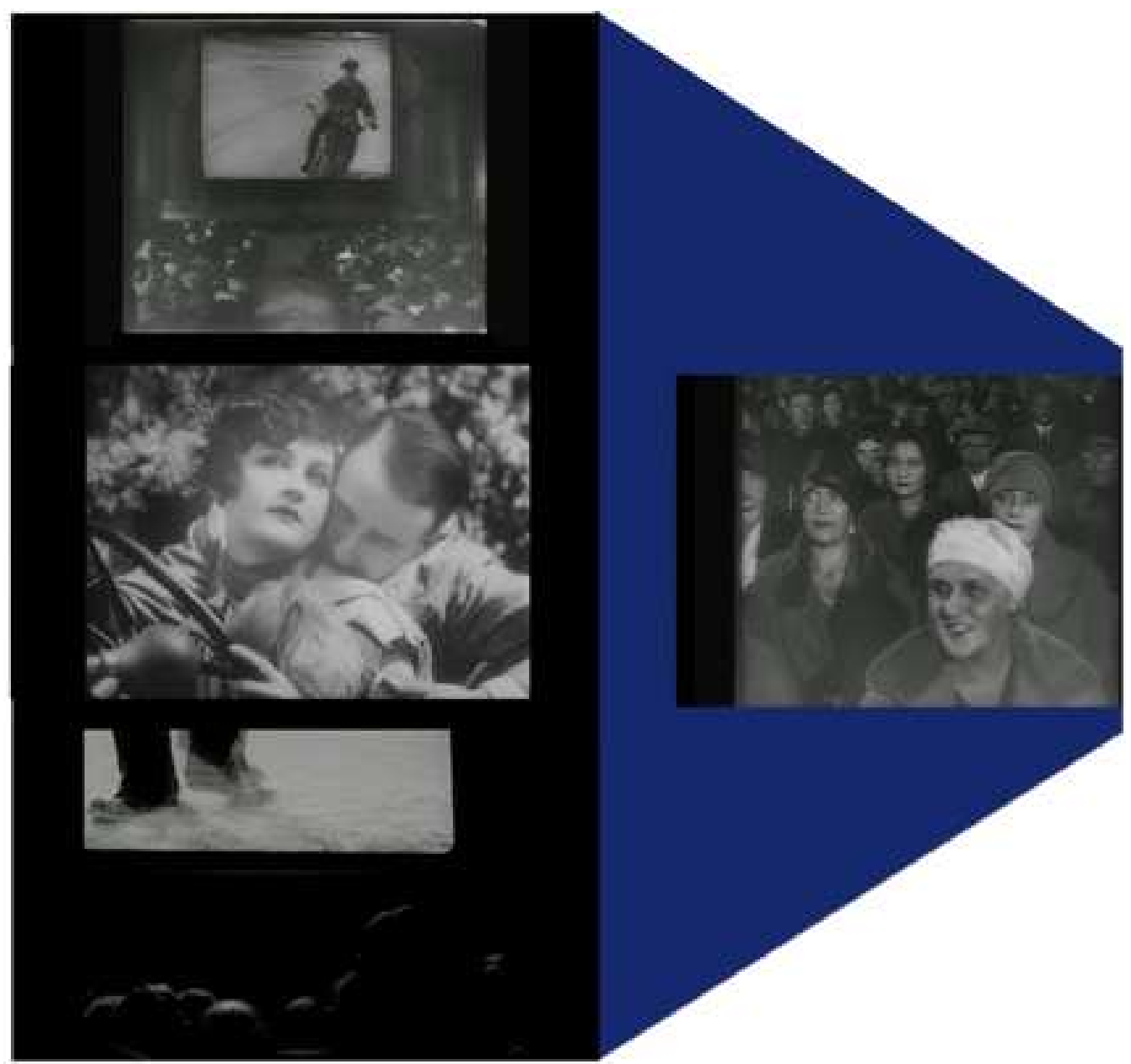

Figura 2. El proceso fílmico vanguardista: del cine-escaparate al metacine. Menschem am Sonntag (Siodmak y Siodmak, dirs., 1930), Berlín (Ruttmann, dir., 1927) y El hombre de la cámara (Vertov, dir., 1929).

La ciudad moderna acabó funcionando en sí misma como escaparate; con las exposiciones universales y el auge del turismo, las ciudades comienzan un trabajo de promoción de sus encantos y se adaptan para acoger a los visitantes temporales. Se elaboran guías, se editan postales, se crean recorridos turísticos especiales y se establece lo que es digno de ser visitado y lo que no. La ciudad se convierte así en una mercancía consumible de un vistazo, que está en permanente exposición. En Montparnasse, poème du café crème (Deslaw, dir., 1929), vemos a los turistas consultar libros, mirar las postales y reconocer el barrio. A propos de Nice (Vigo y Kaufman, dirs., 1930) presenta una visión más ácida; se critica el lujo y desenfreno de una ciudad devota de sus turistas mientras obliga a vivir en la miseria a sus trabajadores.

El escaparate puede entenderse en sentido amplio como una serie de mecanismos de exhibición idealizada y fetichizante del sistema al mismo nivel que la publicidad, el cine o incluso el cuerpo. El cuerpo se presenta en la modernidad como materialización de un 
estilo de vida o de una identidad. El auge de la moda, por una parte, y del higienismo y la estética del deporte, por otra, son las dos tendencias principales de la época en relación al cuerpo.

La moda y el escaparate aprovechan el cuerpo para vender deseo; el cuerpo femenino se convierte en el maniquí predilecto, las mujeres aparecen en los escaparates como cuerpos íntegros 0 descompuestos en partes, se animan a través del uso de autómatas, acercando más el escaparate al ocio y al espectáculo.

La sexualidad se representa en el cine de vanguardia, como hemos visto, de manera mecanizada y extrañada. Sus intenciones van desde mostrar los nuevos objetos industriales, tan cercanos al hombre que terminan adquiriendo la capacidad de dar y recibir placer, hasta una crítica irónica en la que se advierte sobre la mecanización y la frialdad de las relaciones sexuales en la modernidad.

La relación entre el sexo y la máquina se desarrolla ampliamente en la cultura visual de los años 20. El popular espectáculo de las Tiller Girls es una de las muestras más significativas. Kracauer estudió sus repercusiones ideológicas sobre la conciencia, y denominó a este tipo de fenómenos el "ornamento de las masas". El cuerpo se desmaterializa para materializar una forma colectiva geométrica superior en la que las connotaciones sexuales que tendrían grupos de mujeres semidesnudas son eliminadas por lo pulcro de la organización geométrica de esos cuerpos. Mientras el cuerpo humano pierde sexualidad, la adquiere lo inorgánico como hemos observado en los maniquíes de Léger. Podemos encontrar representaciones de las Tiller Girls en muchas películas de vanguardia, por ejemplo, en Berlín o en Six et demi-onze (Epstein, dir., 1927).

La figura humana enrolada en el ornamento de la masa ha comenzado su éxodo desde el exuberante esplendor orgánico y la constitución de la individualidad hacia el reino del anonimato, al cual se abandona cuando la verdad es obstaculizada y cuando el conocimiento que irradia la raíz humana disuelve sus contornos como forma visible natural. En el ornamento de las masas, la naturaleza es privada de su sustancia. (Kracauer 1995: 83)

El cuerpo devino medio de redención, no sólo por el consumo que lo embellecía y así ayudaba a trascender las miserias de la vida, sino porque se instauró un culto al cuerpo sano y atlético gracias al deporte y a las políticas de salubridad urbana. Tanto en el cine como en los escaparates dominaba la fascinación por los cuerpos hermosos y jóvenes. Aún así, en algunos filmes se da visibilidad social a la enfermedad provocada por las insalubres condiciones de vida y de trabajo para deconstruir la fantasmagoría fílmica, como en Im 
Schatten der Maschine (Blum, dir., 1928), Finis Terrae (Epstein, dir., 1929), Impressionen vom alten Marseiller Hafen (Moholy-Nagy, dir., 1929), Ménilmontant (Kirsanoff, dir., 1926) o À propos de Nice (Vigo y Kaufman, dirs., 1930).

La explotación del cuerpo para la viabilidad del sistema se observa tanto en las manifestaciones culturales de los países capitalistas como en los socialistas. Los rasgos que diferencian esta presentación de los cuerpos son distintos. En uno se presenta una mujer fuerte y autónoma, una trabajadora, su cuerpo es pura producción. En el otro, la mujer es delicada y dependiente, su cuerpo es empleado para fomentar el deseo y el consumo.

\section{El tiempo de las arquitecturas efímeras}

La fugacidad del contenido del escaparate, su constante cambio contribuía también a la explotación irracional del deseo. El fenómeno del aumento y la aceleración del consumo fue relacionado por algunos contemporáneos con la concepción temporal de la época: el tiempo es oro y el consumo ha de ser frenético. Éste puede entenderse como lucha a contratiempo para aprovechar al máximo todas las posibilidades de experiencia (mediadas por el consumo) que ofrece la ciudad. Esta necesidad de reaccionar rápido antes de que el instante se extinga, se veía intensificada por el carácter de novedad inscrito en la moda: cada temporada es distinta, si no se consume en ese momento, se pierde para siempre la oportunidad. Esta dinámica es la que subyace en la renovación cíclica de los escaparates para estimular el consumo. Consumir el contenido de esas escenografías efímeras antes de que desaparecieran para poder estar a la moda, para construir una identidad a través de la apariencia, incrementa el frenesí y la irracionalidad en el consumo de esos fetiches.

La moda, a su vez, contribuye a la acentuación de la conciencia del tiempo de forma concreta, el ser y el no ser, la línea divisoria del pasado y el presente; la moda, estudiada por Georg Simmel, "nos aporta, como pocos fenómenos, una intensa sensación de actualidad" (Simmel apud Frisby 1992: 182). La moda se convierte también en una forma de expresar la individualidad ausente, señalar una distinción a la vez que una integración, es "un vehículo para que el individuo indique exteriormente su posición respecto de la sociedad en conjunto" (Frisby 1992: 184). La moda encarna también la dialéctica entre lo transitorio y lo eterno, pues nace como con voluntad de vivir eternamente: es el eterno retorno de lo sempiterno. La circulación de la moda es como la de la mercancía, siempre nueva y a la vez siempre la misma. Los individuos tratan de realizar sus valores en la cultura objetiva; y esto lo hacen en una cultura objetiva sin contenido real. Simmel afirmaba que el contenido de la moda es inexistente, cada novedad sólo sirve parar crear un movimiento de recolocación social que lleva a la gente a retomar su puesto 
BARREIRO, Ma Soliña (2014): "Escenografías del deseo urbano. El escaparate como espacio fantasmal y límbico en el cine de vanguardia de los años 20" [en línea]. En: Ángulo Recto. Revista de estudios sobre la ciudad como espacio plural, vol. 6, núm. 2, pp. 65-83. En: http://www.ucm.es/info/angulo/volumen/Volumen06-2/articulos04.htm. ISSN: 1989-4015 http://dx.doi.org/10.5209/rev_ANRE.2014.v6.n2.47584

visualizable por medio de la adquisición de la nueva moda.

La novedad añade un rasgo más a la mercancía que profundiza en su fetichismo, ya que

[...] no depende del valor de uso de la mercancía. Es el origen de la ilusión que corresponde inalienablemente a las imágenes que engendra el inconsciente colectivo. Es la quintaesencia de la conciencia falsa cuyo incansable agente es la moda. Esa ilusión de la novedad se refleja, como un espejo en otro, en la ilusión de la eternidad de lo sempiterno. (Benjamin apud Frisby 1992: 456)

El carácter cíclico de la moda se aplica a la industria del entretenimiento en general. Se estimula un prometedor retorno de lo mismo en el fin de semana, con un viaje, con una película; se presenta como una ruptura, como un alejamiento de lo cotidiano bien planeado por la industria del ocio para que nunca decaiga el deseo. Este ocio cíclico tiene además la función de ayudar a los trabajadores a soportar sus rutinas gracias a la promesa de esa pequeña liberación. La organización de la industria del ocio fue sistemática; copió el week-end del modo de vida americano y lo convirtió en mercancía, en una atracción de masas. La película Menschem am Sonntag (Siodmak y Siodmak, dirs., 1930) da cuenta de este fenómeno.

No sólo el ocio se transforma bajo el influjo de la mercancía sino también la comprensión de la historia. La información y su asimilación dependen también en los grandes medios de la novedad última y exclusiva, de la constante renovación de informaciones sin que necesariamente ninguna sea trascendente. "El colectivo onírico no conoce historia alguna. Para él, el curso del acontecer fluye como lo mismo de siempre y lo novísimo de siempre. $Y$ es que la sensación de lo más nuevo y moderno es una forma onírica del acontecer tanto como el eterno retorno de lo mismo" (Benjamin 2005: 561). Los sentidos se embotan, cada vez tiene que ser mayor la sensación de novedad y la comprensión se reduce al quedarse atrapada en lo nuevo por lo nuevo.

La mediación del deseo y de la vida se producía en los primeros años del siglo XX a través de todo tipo de escaparates, desde los medios de comunicación a las exposiciones universales, desde el cine a los propios vidrios que inundaban las calles con mercancías. Esta diversidad de escenografías efímeras del deseo envolvía la vida moderna en un simulacro de existencia que le permitía desplegar su doble función (ideológica y estética) en todas las esferas de la vida. Así, estos dispositivos, luminosos, transparentes y omnipresentes, conectaban la esfera interna del deseo humano con su esfera externa por medio de la puesta en escena espacial (cinematográfica, mercantil, expositiva). La vida se encontraba invadida por una 
membrana interactiva cada vez más extensa que lograba objetivar los deseos, trasladarlos a la esfera material; y todo ello a la vez que ocultaba las relaciones de producción que se hallaban en su origen, imposibilitando el uso de la razón no instrumental para comprender las condiciones de la existencia, para liberarse del manto deslumbrante de deseos que pueden ser comprados y consumidos pero que jamás podrán consumarse. "Este es el aspecto que presentaban el mundo y la sociedad [...]: la vida está totalmente encadenada a un entramado que la mantiene cautiva [...]. Da igual cómo se haya llegado a ese estado de cosas; está ahí y nadie puede substraerse a él" (Ball 2005: 27).

\section{Bibliografía}

AA VV (1983): Le libre des Expositions Universelles. Delegación para las Artes Plásticas del Ministerio de Cultura francés y Unión Central de las Artes Decorativas. París: Herscher.

AGAMBEN, Giorgio (2006): Estancias: la palabra y el fantasma en la cultura occidental. Valencia: Pre-Textos.

BALL, Hugo (2005): La huida del tiempo. Barcelona: Acantilado.

BENJAMIN, Walter (2005): Libro de los Pasajes. Madrid: Akal.

BUENO Sonia; y PEIRANO, Marta (eds.) (2009): El Rival de Prometeo. Vidas de autómatas ilustres. Madrid: Impedimenta.

DESLAW, Eugène (1929): "Après mes premières". L'indépendance belge, núm. 6.

EISENSTEIN, Serguei M.; y ALBERA, François (2009): Glass House: du projet de film au film comme projet. Dijon: Les presses du réel.

FRISBY, David (1992): Fragmentos de la Modernidad. Teorías de la Modernidad en la obra de Simmel, Kracauer y Benjamin. Madrid: La balsa de la Medusa.

HESSEL, Franz (1997): Paseos por Berlín. Madrid: Tecnos.

KRACAUER, Siegfried (1995): The Mass Ornament. Weimar Essays. Londres / Cambridge: Harvard University Press.

KRACAUER, Siegfried (2002): De Caligari a Hitler: Una historia psicológica del cine alemán. Barcelona: Paidós.

LUNGSTRUM, Janet Ward (1999): "The Display Window: Designs and Desires of Weimar Consumerism". New German Critique, núm. 76, pp. 115-160.

MARX, Karl (2000): El Capital. Madrid: Akal.

WARD LUNGSTRUM, Janet (2001): Weimar Surfaces: Urban Visual Culture in 1920s Germany. Berkeley: University of California Press. 
BARREIRO, Ma Soliña (2014): "Escenografías del deseo urbano. El escaparate como espacio fantasmal y límbico en el cine de vanguardia de los años 20" [en línea]. En: Ángulo Recto. Revista de estudios sobre la ciudad como espacio plural, vol. 6, núm. 2, pp. 65-83. En: http://www.ucm.es/info/angulo/volumen/Volumen06-2/articulos04.htm. ISSN: 1989-4015 http://dx.doi.org/10.5209/rev_ANRE.2014.v6.n2.47584

\section{Filmografía}

BLUM, Albrecht Viktor (dir.) (1928): Im Schatten der Maschine. Alemania: Film-Kartell "Weltfilm" GmbH.

CAVALCANTI, Alberto (dir.) (1926): Rien que les heures (Simplemente las horas). Francia: s.p.

DESLAW, Eugéne (dir.) (1929): Montparnasse, poème du café crème (Montparnasse, poema del café con leche). Francia: Archives du Film / Cinémathèque Française.

DESLAW, Eugéne (dir.) (1930): Les nuits eléctriques. Francia: s.p.

EPSTEIN, Jean (dir.) (1923): Cœur Fidèle (Corazón fiel). Francia: Pathé Consortium Cinéma.

EPSTEIN, Jean (dir.) (1927): Six et demi onze. Francia: Films Jean Epstein.

EPSTEIN, Jean (dir.) (1929): Finis Terrae. Francia: Société Générale des Films.

KIRSANOFF, Dimitri (dir.) (1926): Ménilmontant. Francia: s.p.

LANG, Fritz (dir.) (1931): M (M, el vampiro de Düsseldorf). Alemania: Nero Film AG.

LÉGER, Fernand ; y MURPHY, Dudley (dirs.) (1924): Ballet mécanique (El ballet mecánico). Francia: s.p.

MOHOLY-NAGY, Lazslo (dir.) (1929): Impressionen vom alten Marseiller Hafen. Alemania: s.p.

MURNAU, F. W. (dir.) (1927): Sunrise: A Song of Two Humans (Amanecer). Estados Unidos: Fox Film Corporation.

PORTER, Edwin S. (1905): Coney Island at night. Estados Unidos: Edison Manufacturing Company.

RAY, Man (dir.) (1926): Emak-Bakia. Francia: s.p.

RENOIR, Jean (dir.) (1928): La petite marchande de allumettes (La cerillera). Francia: s.p.

RUTTMANN, Walther (dir.) (1927): Berlin, Die Sinfonie der Grosstadt (Berlín, sinfonía de una gran ciudad). Alemania: Deutsche VereinsFilm / Les Productions Fox Europa.

SIODMAK, Curt; y SIODMAK, Robert (dirs.) (1930): Menschem am Sonntag (Hombres en domingo). Alemania: Filmstudio Berlin.

VERTOV, Dziga (dir.) (1926): Shagay, sovet! (Adelante Soviet). URSS: Goskino.

VERTOV, Dziga (dir.) (1926): Shestaya chast mira (La sexta parte del mundo). URSS: Sovkino.

VERTOV, Dziga (dir.) (1929): Cheloveks kino-apparatom (El hombre de la cámara). URSS: VUFKU.

VIGO, Jean; y KAUFMAN, Boris (dirs.) (1930): $\grave{A}$ propos de Nice (A propósito de Niza). Francia: s.p. 